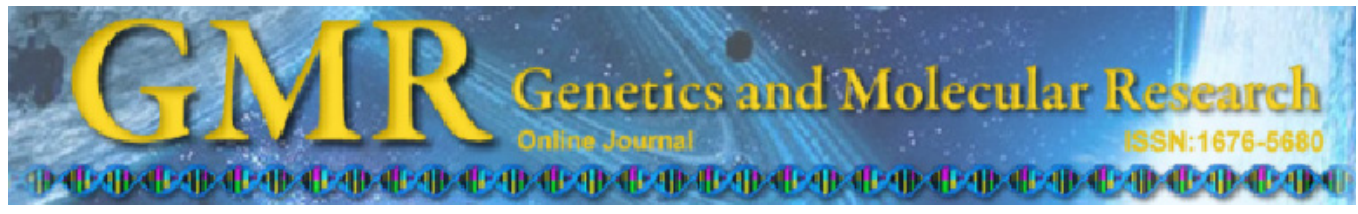

\title{
Epstein-Barr virus DNA associated with gastric adenocarcinoma and adjacent non-cancerous mucosa in patients from Manaus, Brazil
}

\author{
P.F. de Aquino ${ }^{1}$, P.C. Carvalho ${ }^{2}$, J.S. da Gama Fischer ${ }^{2}$, A.Q.L. de Souza ${ }^{3}$, \\ J.S. Viana ${ }^{3}$, S.R.S. Chalub ${ }^{4}$, A.D.L. de Souza ${ }^{1}$ and M.G.C. Carvalho ${ }^{5}$ \\ ${ }^{1}$ Departamento de Química, Universidade Federal do Amazonas, \\ Manaus, AM, Brasil \\ ${ }^{2}$ Instituto Carlos Chagas, Fiocruz, Curitiba, PR, Brasil \\ ${ }^{3}$ Escola Superior de Ciências da Saúde, Universidade do Estado do Amazonas, \\ Manaus, AM, Brasil \\ ${ }^{4}$ Departamento de Cirurgia Digestiva, Universidade Federal do Amazonas, \\ Manaus, AM, Brasil \\ ${ }^{5}$ Instituto de Biofísica Carlos Chagas Filho, \\ Universidade Federal do Rio de Janeiro, Rio de Janeiro, RJ, Brasil \\ Corresponding author: M.G.C. Carvalho \\ E-mail: gloria@gcarvalho.org
}

Genet. Mol. Res. 11 (4): 4442-4446 (2012)

Received March 23, 2012

Accepted May 28, 2012

Published October 15, 2012

DOI http://dx.doi.org/10.4238/2012.October.15.3

\begin{abstract}
Gastric cancer is one of most frequent causes of death in Brazil. The city of Manaus has one of the highest incidences of this disease in Brazil. The Epstein-Barr virus (EBV) is a ubiquitous herpesvirus that is classified as a group 1 carcinogen by the International Agency for Research on Cancer. We obtained biopsies from 6 control subjects and 10 patients with gastric carcinomas living in Manaus. In the patients, the samples were taken from tumors and from adjacent non-cancerous mucosa. These samples were screened for EBV DNA by PCR to amplify the 288-bp fragments from the Bam M region. The
\end{abstract}


EBV DNA was detected in 8 of the 10 tumor cases and in none of the 6 control subjects. In the positively identified samples, EBV DNA was detected in five corresponding resection margins. Previous research indicated only a weak association between EBV and gastric cancer. We suggest that EBV should be considered as a risk factor for gastric adenocarcinomas in Manaus.

Key words: Epstein-Barr; Gastric cancer; Amazon; Resection margin; Polymerase chain reaction

\section{INTRODUCTION}

Gastric cancer (GC) is one of the most common cancers, and is ranked 2nd among the worldwide cancer mortality rates (Ebert et al., 2006). Several factors may contribute individually or together to the emergence of this neoplasia, including infection with Helicobacter pylori, dietary habits, genetic factors, and viral infections (Schulz, 2005). GC is mostly found in individuals aged over 50 years; its incidence in individuals under 40 years corresponds to only 5\% of all cases (Theuer et al., 1996; Mauad et al., 2000). Most patients are diagnosed with GC in an advanced state, thus drastically reducing the treatment options, survival, and cure (Ebert et al., 2006). In the northern part of Brazil, GC is the 2nd most common cancer in men and the 4th in women, accounting for an estimated 13 and 7 new cases per 100,000 per year for men and women, respectively (Guerra et al., 2005; INCA, 2012). While most GCs are correlated with H. pylori infection (Asaka et al., 1994; Komoto et al., 1998), such is not true for cases in the Brazilian State of Amazonas, were most GC patients are $H$. pylori negative. These facts motivated our group to investigate other risk factors to help explain this high incidence.

The incidence of the Epstein-Barr virus (EBV) with GC has been found to vary from 2 to $18 \%$ in the world population. A recent Brazilian report described an incidence of $\sim 8 \%$ among GCs from Ceará (Lima et al., 2011). Thus, we considered investigating whether EBV could be correlated with GC in the Amazon.

EBV is classified as a group 1 carcinogen according to the International Agency for Research on Cancer (IARC). It belongs to the gamma-herpes family, which has a linear DNA molecule responsible for encoding approximately 100 proteins (Silva and Zucoloto, 2003; Lima and Rabenhorst, 2006). Reports describe more than $90 \%$ of our population as being previously exposed to EBV, which can be easily transmitted by salivary contact (Macsween and Crawford, 2003). This virus has 2 distinct life cycles in the human host: a lytic cycle, during which the production of new virions occurs, and a latent form, wherein it remains in a dormant state for the lifetime of the host (Pattle and Farrell, 2006). EBV is mostly well known as the causative agent for infectious mononucleosis, which is usually manifested in adulthood through latent EBV genes (Asaka et al., 1994). In addition to GC, EBV has been associated with malignancies including Burkitt's lymphoma, Hodgkin's disease, peripheral T-cell lymphoma, thymoma, and nasopharyngeal carcinoma (Lima and Rabenhorst, 2006). The role of EBV in tumorigenesis is not well understood, but there is evidence correlating its persistence in human epithelial cells with tumorigenesis (Tsao et al., 2012). 


\section{MATERIAL AND METHODS}

\section{Subjects}

This study was approved by the Ethics Committee Review Board from the Federal University of the Amazon (CEP/UFAM: MEMO - No. 0057.0.115.000-11-CAAE). After signing informed consent, tumor specimens with resection margins were obtained after surgery from $10 \mathrm{GC}$ patients, 4 females. Six biopsies were obtained from control subjects during upper endoscopy; 5 were from females. Subjects were classified as controls if no traces of cancer were detected by endoscopic evaluation. All biopsies were obtained from the stomach. Each biopsy was then subtyped and the clinical stage of the disease was determined according to the tumor, node, and metastasis classification (TNM) from the American Joint Committee on Cancer (AJCC).

\section{DNA extraction}

For the polymerase chain reaction (PCR) analysis, the biopsies were pulverized and genomic DNA was isolated by digestion in $500 \mu \mathrm{L}$ containing $10 \mathrm{mM}$ Tris- $\mathrm{HCl}, \mathrm{pH} 7.5,10$ $\mathrm{mM} \mathrm{NaCl}, 2 \% \mathrm{SDS}, 10 \mathrm{mM}$ EDTA, $\mathrm{pH} 8.0$, and $15 \mu \mathrm{L}$ proteinase $\mathrm{K}(10 \mathrm{mg} / \mathrm{mL})$. The material was incubated at $56^{\circ} \mathrm{C}$ for $2 \mathrm{~h}$; DNA was then extracted by phenol-chloroform-isoamilic alcohol and resuspended in sterile distilled water. The extracted genomic DNA was submitted to PCR to confirm DNA integrity using p53 primers to exon 5, generating a 274-bp product (Pestaner et al., 1994).

\section{PCR for detecting EBV DNA in the biopsies}

The detection for EBV DNA used the primers TC67 and TC69, which amplify a portion of the Bam M region of EBV DNA and produce a 288-bp product (Saito et al., 1989). Amplification conditions consisted of an initial denaturation step at $95^{\circ} \mathrm{C}$ for $5 \mathrm{~min}$ followed by 35 cycles of $95^{\circ} \mathrm{C}$ for $1 \mathrm{~min}, 60^{\circ} \mathrm{C}$ for $1 \mathrm{~min}$, and $72^{\circ} \mathrm{C}$ for $1 \mathrm{~min}$. This was followed by a final extension step at $72^{\circ} \mathrm{C}$ for $5 \mathrm{~min}$. For all reactions we used positive (viz., DNA from Raji cells) and negative (viz., Milli-Q water) controls (Lattario et al., 2008).

\section{Diagnosis of EBV DNA}

Diagnosis was accomplished by visually inspecting for the presence of 288-bp PCR products using a $10 \%$ polyacrylamide gel stained with silver nitrate (Rosenbaum and Riesner, 1987). The approximate size of the amplified fragments was calculated using co-electrophoresis with low molecular weight (BioRad).

\section{RESULTS}

The results from our analysis for the presence of $H$. pylori and EBV DNA are presented in Table 1. Briefly, EBV DNA was detected in $80 \%$ of the biopsies, among which $50 \%$ had positive resection margins. EBV DNA was not found in any control subjects. 
Table 1. Clinical and experimental features for the presence of Epstein-Barr virus (EBV) from subjects enrolled in the study.

\begin{tabular}{rllclccc}
\hline No. & Type & Gender & Age (years) & Diagnosis & Helicobacter pylori & EBV DNA cancer & EBV DNA RM \\
\hline 1 & Control & F & 46 & Gastritis & - & - & NA \\
2 & Control & F & 26 & Gastritis & - & - & NA \\
3 & Control & F & 52 & Gastritis & - & - & NA \\
4 & Control & M & 43 & Gastritis & - & - & NA \\
5 & Control & F & 55 & Gastritis & - & - & NA \\
6 & Control & F & 62 & Gastritis & - & + & + \\
7 & Cancer & F & 49 & T4N3M0 & - & - & + \\
8 & Cancer & F & 71 & T3NXM0 & - & - & - \\
9 & Cancer & M & 48 & T4NXM0 & - & + \\
10 & Cancer & F & 46 & T4N0M0 & + & + & + \\
11 & Cancer & F & 46 & T4NXN0 & - & + \\
12 & Cancer & M & 47 & T3N3M0 & - & - \\
13 & Cancer & M & 68 & T3NXM0 & - & + \\
14 & Cancer & M & 50 & T4NXM1 & - & + \\
15 & Cancer & M & 40 & T1NXM0 & - & + \\
16 & Cancer & M & 62 & T4N2M1 & + & + \\
\hline
\end{tabular}

$\mathrm{RM}=$ resection margin; $\mathrm{F}=$ female; $\mathrm{M}=$ male; $(+)$ or $(-)=$ presence or not of $H$. pylori and $\mathrm{EBV}$, respectively; $\mathrm{NA}=$ not applicable.

\section{DISCUSSION}

Previous studies have described H. pylori as the main causative agent for GC (Asaka et al., 1994; Komoto et al., 1998) and report a low correlation between EBV and GC (Lima and Rabenhorst, 2006; Lima et al., 2011). Here, EBV DNA was detected in $80 \%$ of the tumors examined using PCR, and 50\% presented EBV DNA in both the GC specimen and the resection margin. EBV was detected in both early and advanced stages of GC, as aligned with previous reports (Shibata et al., 1991; Sample and Sample, 2008). It is also important to emphasize that H. pylori was detected in only 2 cases. As such, although EBV's mechanisms for triggering carcinogenesis are not well understood (Nishikawa et al., 1999), our results suggest that EBV should be considered as a risk factor for this disease, especially in the Amazon State, Brazil.

An increased sample size will be necessary to accomplish a more robust statistics. Regardless, we have raised an important hypothesis of a high correlation between EBV and $\mathrm{GC}$ in the Amazon that deserves further investigation by the scientific community in different and larger cohorts.

\section{ACKNOWLEDGMENTS}

The authors thank the medical team of the CECON foundation for assisting with the samples. Research supported by CAPES, CAPES/Fiocruz 2006/2, CNPq, Fundação do Câncer, and FAPEAM.

\section{REFERENCES}

Asaka M, Kimura T, Kato M, Kudo M, et al. (1994). Possible role of Helicobacter pylori infection in early gastric cancer development. Cancer 73: 2691-2694.

Ebert MP, Niemeyer D, Deininger SO, Wex T, et al. (2006). Identification and confirmation of increased fibrinopeptide a serum protein levels in gastric cancer sera by magnet bead assisted MALDI-TOF mass spectrometry. J. Proteome 
Res. 5: 2152-2158.

Guerra MR, Gallo CVM, Azevedo G and Mendonça S (2005). Risco de câncer no Brasil: tendências e estudos epidemiológicos mais recentes. Rev. Bras. Cancerol. 51: 227-234.

INCA (2012). Instituto Nacional do Câncer/Estimativa 2012: Incidência de Câncer no Brasil. Available at [http://www. inca.gov.br/estimativa/2012/estimativa20122111.pdf]. Accessed January 20, 2012.

Komoto K, Haruma K, Kamada T, Tanaka S, et al. (1998). Helicobacter pylori infection and gastric neoplasia: correlations with histological gastritis and tumor histology. Am. J. Gastroenterol. 93: 1271-1276.

Lattario F, Furtado YL, Fonseca R, Silveira FA, et al. (2008). Analysis of human papillomavirus and Epstein-Barr virus infection and aberrant death-associated protein kinase methylation in high-grade squamous intraepithelial lesions. Int. J. Gynecol. Cancer 18: 785-789.

Lima MAP and Rabenhorst SHB (2006). Association of Epstein-Barr virus (EBV) with solid tumors. Rev. Bras. Cancerol. 52: 87-96.

Lima MAP, Ferreira MVP, Barros MAP, Pardini MIMC, et al. (2011). Epstein-Barr virus (EBV) detection in gastric carcinomas from Ceará and São Paulo states, in Brazil. J. Bras. Patol. Med. Lab. 47: 171-179.

Macsween KF and Crawford DH (2003). Epstein-Barr virus-recent advances. Lancet Infect. Dis. 3: 131-140.

Mauad EC, Nogueira JL, Souza JMP, Wohnrath DR, et al. (2000). Câncer gástrico em adultos jovens. Rev. Bras. Cancerol. 46: 299-304.

Nishikawa J, Imai S, Oda T, Kojima T, et al. (1999). Epstein-Barr virus promotes epithelial cell growth in the absence of EBNA2 and LMP1 expression. J. Virol. 73: 1286-1292.

Pattle SB and Farrell PJ (2006). The role of Epstein-Barr virus in cancer. Expert Opin. Biol. Ther. 6: 1193-1205.

Pestaner JP, Bibbo M, Bobroski L, Seshamma T, et al. (1994). Potential of the in situ polymerase chain reaction in diagnostic cytology. Acta Cytol. 38: 676-680.

Rosenbaum V and Riesner D (1987). Temperature-gradient gel electrophoresis. Thermodynamic analysis of nucleic acids and proteins in purified form and in cellular extracts. Biophys. Chem. 26: 235-246.

Saito I, Servenius B, Compton T and Fox RI (1989). Detection of Epstein-Barr virus DNA by polymerase chain reaction in blood and tissue biopsies from patients with Sjogren's syndrome. J. Exp. Med. 169: 2191-2198.

Sample JT and Sample CE (2008). Epstein-Barr Virus: Molecular Biology. Encyclopedia of Virology, 3rd edn. Elsevier Ltd., Oxford, 157-167.

Schulz WA (2005). Molecular Biology of Human Cancers - An Advanced Student's Textbook. Springer, Dordrecht.

Shibata D, Shibata D, Uemura Y, Sato E, et al. (1991). Association of Epstein-Barr virus with undifferentiated gastric carcinoma with intense lymphoid infiltration lymphoepitheliomalike carcinoma. Am. J. Pathol. 139: 469-474.

Silva AR and Zucoloto SO (2003). The role of Epstein-Barr virus in human tumorigenesis. Medicina 36: 16-23.

Theuer CP, de Virgilio C, Keese G, French S, et al. (1996). Gastric adenocarcinoma in patients 40 years of age or younger. Am. J. Surg. 172: 473-476.

Tsao SW, Tsang CM, Pang PS, Zhang G, et al. (2012). The biology of EBV infection in human epithelial cells. Seminars Cancer Biol. 22: 137-143. 